\title{
The Austrian Tertius Gaudens: A Revisit of Competition Theory in Light of Georg Simmel
}

\author{
ANDERS LILJENBERG \\ Stockholm School of Economics, P.O. Box 6501, SE-113 83 Stockholm, Sweden
}

Anders.Liljenberg@hhs.se

\begin{abstract}
Austrian market process theory stands out in assigning particular importance to the role of the customer. This is however not really salient as competition is discussed save for in a few particular instances. This is a pity since the market process discourse thereby deprives itself of a firm progressive footing concerning further elaborations of how market dynamics evolve. By drawing on the reasoning that originates some hundred years ago with the works of Georg Simmel, this paper brings forward an Austrian version of his idea on Tertius Gaudens. In a market context this is the alert buyer who benefits from the disunion that prevails between sellers to the extent that market intimacy, conceived of as supplier specificity, is low. In this manner some of the inner workings of the market process, what promotes competition subject to which institutional constraints, are discussed to the benefit of yet another important Austrian demarcation, that of competition as being geared by the customer.
\end{abstract}

Key Words: competition, supplier specificity, entrepreneurship, Tertius Gaudens

JEL classification: A12, B53, M13, Z13

\section{Introduction}

Despite the undisputable fact that the way in which a market works is subject not only to supply considerations but also to customer conduct, this line of reasoning is strikingly absent in economics' shouldering of competition. This holds also outside the immediate mainstream realm as sellers are recognized not only as takers but also as makers of price (confer Kirzner 1973). The omission of the customer as constituting a particular market agency dates back all the way to early 18 th century as Bernard Mandeville (1970 [1705]) lays the solid formation for what later on will emerge as the scholarly treatment of competition in political economy and neoclassical economics. It remains when Cournot formalizes the argument some hundred years later and stays on as microeconomics becomes yet more sophisticated until present days. This discourse is typically elaborated as more and more finetuned facets of price theory are presented. According to this predominant view, competition appears as a mostly structural input, typically expressed as the sheer number of sellers and/or the homo-/heterogeneous character of goods, for further pricing analysis. That is to say, the vast majority of works in the area does not properly observe the role of the customer for how competition develops in supply markets. Other things are more crucial to focus.

But, '[t]he consumer is also a maker', of her own immediate well-being and of the supply context (inter alia the market structure and sellers' offers) wherein discovery of market opportunities unfolds (confer Bianchi 1998a, b). Under certain conditions this proneness 
of some buyers expresses consumer sovereignty according to which market process ends are deliberately pondered upon by customers in a discretionary manner (confer Hutt 1940). Such reasoning is foreshadowed in Galbraith's (1993 [1952]) idea on countervailing market forces according to which the power of influential buyers could impact competition among sellers (confer Koppl 2002 for a somewhat similar stance). These ideas are to some extent further elaborated upon in a few strands of contemporary game-theoretic analysis that discuss how horizontal competition and vertical auction-like bidding procedures are intertwined. Among the Austrians, the most salient discussion of how customers impact competition is notably that of Mises (1963 [1949]) on consumer sovereignty in the market process. But not even in the Austrian school is this intuitive parameter much of an issue since the interlinkage of competition and seller entrepreneurship is put to the fore.

This omission of economics for a true understanding of the market process, that competition cannot be properly grasped without recognizing buyer influence, is however mitigated when some works of the German sociologist Georg Simmel are scrutinized (confer Simmel 1950 [1908], 1955 [1908]). By his subtle though yet ingenious observation that ' $[t]$ he foremost sociological characteristic of competition is the fact that conflict in it is indirect', Simmel invites the customer as the 'third who benefits from the disunion of the two'. And by thus launching the idea of Tertius Gaudens he, although unknowing at the time, manages to put forward some of the bricks which are still missing in contemporary economics' edifice of the market. Apart from providing a platform for the exploitation of some unchartered territory in the area of consumer choice impact on competition, following in Simmel's footsteps implies an opportunity of accommodating the tension between intimacy and anonymity in the market. This tension can be explored through the notion of supplier specificity which is the particular institutional context wherein customer entrepreneurship works out. A high degree of specificity implies market intimacy and less of entrepreneurial scope for competition promotion and vice versa.

The paper here underway sets out to integrate these ideas of Simmel's into the Austrian agenda thereby enriching this most promising ground for market process understanding. This endeavor will unfold in a few distinct steps as follows. First of all a recapitulation of some mainstream economics will tell about how competition, and the eventual customer impact thereupon, can be framed. Thereafter a corresponding argument, but this time from an Austrian horizon, will be made. And it will be shown that the explicit infusion of customer influence into competition dynamics fits neatly with the market process view. Then time will be ripe for an outline of Simmel's ideas followed by a discussion of how the scope for customer entrepreneurship is conditioned by the relevant institutional context, here the level of market intimacy conceived of as supplier specificity. The conclusive paragraph discusses how this particular view is coherent with Austrian reasoning. It is then observed that whereas Mises' view on consumer sovereignty is close to the 'active' Tertius, its 'passive' counterpart mirrors the entrepreneurial alertness as discerned by Kirzner. In this final section the contours of an Austrian Tertius Gaudens are also laid bare in the guise of a formulation of competition that sees it as a function of promoting and impeding forces respectively, all of which originating with the customer. 


\section{The Customer in Mainstream Competition Theory}

A leading neoclassical scholar like Stigler (1987: 531-535) identifies competition as 'rivalry ... [that] arises whenever two or more parties strive for something that all cannot obtain'. The behavioral objectives of at least two parties are hence mutually exclusive. This most generic view is made more specific as Stigler homes in on the very idea of perfect competition by articulating some of the precise conditions that are deemed necessary therefore. Such 'central elements of competition' encompass but are not limited to the freedom of resource deployment and the exchange thereof at any price by an indefinite number of independent buyers and sellers who share full knowledge as regards all exchange opportunities. In this idealized state price is parametric which implies that all sellers are price-takers since they cannot impact market pricing by altering the volume of any commercialized product. As pointed out at some length elsewhere (confer Kirzner 1973, Mc Nulty 1968) there is obviously somewhat of a contradiction here since 'competition as rivalry' (dynamic and behavioral in character) cannot possibly be similar to the most structural notion of 'competition as perfect competition'. ${ }^{1}$ The highly stylized ideal-type perfect competition corresponds very much to the original ideas formalized by Cournot and still pervades the economics discourse at large (confer Dennis 1977, Demsetz 1982, Stigler 1987, Backhouse 1990). ${ }^{2}$ The seeing of competition as 'perfect' is attributable to the manner in which welfare economics ever since sticks to the idea of pareto optimality (confer Vickers 1995:1, Blaug 1997:594). This view also mirrors the explicit predictive aspirations of (positive) economics (confer Friedman 1953) according to which the strengths of any assumptions made are instrumental for the robustness of any model formulated. ${ }^{3}$ The reason is that these "central elements of competition' as proposed by Stigler are in fact identical to the assumptions that underlie the model of perfect competition. And in consequence the formulation of these assumptions, typically pertaining to the character of goods and the number of market participants, also entails the very articulation of competition as such meaning that there is nothing left really to analyze in this regard. Nothing, as the determinateness of equilibrium analysis here is allowed to work out in full. Competition in consequence conforms to, and appears as, one or the other market type conceived of as a set of structural dictums. It is an input to and a facet of predictive pricing analysis. Notwithstanding the many obvious merits of such an approach it leaves competition devoid of any true analysis of its own in addition to its pricing impact. This observation here appears as a matter of registration only as such ambiguity is since long recognized within the discourse of economics (confer Liljenberg 2001 for an elaborated discussion in this area). True, what is put forward above applies less rigidly to works that emanate from the ideas of Chamberlin (1969 [1933]) who starts out in the observation that when modeling competition this should be done in light of its imperfect character (this is obviously the case made by scholars within the industrial organization tradition, confer Scherer and Ross 1990). The assumption of full actor independence is here taken issue with in light of either the low number of sellers and/or the differentiated character of goods. But the structural emphasis is still there.

An additional facet of this ambiguity of perfect competition is its blurring also of the conception of the market. McNulty $(1968: 641,645)$ here claims that 'the failure to distinguish between the idea of competition and the idea of market structure is at the root of much of 
the ambiguity concerning the meaning of competition.' A similar argument is in fact made by Stigler $(1987: 531,533)$ positing that 'the merging of the concepts of competition and the market was unfortunate, for each deserved a full and separate treatment.' But whereas Stigler says 'that even today a market is commonly treated as a concept subsidiary to competition', McNulty (1968:645) has it 'that competition has been conceived of as a concept subsidiary to that of the market rather than the other way around'.

As for customer impact on competition it is not really salient within the neoclassical agenda. What mostly is encountered here is the reactive customer who merely responds to supplier initiatives in a most passive manner. Despite some attention paid to utility functions, demand market structure, and (customer-perceived) product differentiation (as appearing in works on imperfect competition), there is no real customer agency around connected to the prevalence of competition. The prevailing exceptions are found within the discourse on market power as exercised via market demand. The paradox referred to above regarding rivalry vs. perfect competition (is there really any competition in perfect competition?) is obviously the main reason behind this negligence that, it should be said, applies to supplier conduct as well, although maybe to a lesser extent.

The referred market power embodies the potency of buyers that can be structurally conceived of as bilateral monopoly/oligopoly and monopsony/oligopsony respectively. In the case of bilateralism it is obvious that supply and demand market powers are opposed and that indeterminate price leadership will result following bargaining outcome. If now buyer potency is elaborated upon concerning in particular how it affects competitive conditions a firsthand choice is the works of John Kenneth Galbraith on countervailing power. This power is a third disciplining market force in parallel to those of (conventional) competition and state intervention. And customers accordingly have at times got an immense role to play for competition among sellers as such power constitutes a type of disciplining market force that resides in parallel with, or instead of, supplier competition. Galbraith (1993 [1952:110-134]) recognizes the coming into being of not only large suppliers, but also of like customers, something endemic to the fact that very few manufacturers sell directly to consumers but only through multi-staged channels of distribution. ${ }^{4}$ The game-theoretic application of countervailing power, as noted by McAfee and McMillan (1996), is that 'horizontal competition' and 'vertical bidding procedures' can be considered as two clearcut alternatives for a supplier about to sell, or a customer about to buy. Good buyer bargaining skills could act as 'artificial competition' as far as pricing impact is concerned. A talented customer is, via wise negotiation, in the position to attain a price from an oligopolistic or monopolistic supplier that corresponds to that conventionally at hand only in the case of more competition among several suppliers. But this is not a straightforward exercise. If there is a choice, it is mostly preferable for a customer to "place more faith in the power of competition among alternative suppliers than in ... her own negotiating skill' (McAfee and McMillan 1996:265). The game-theoretic ground for this is that competition is more 'robust' than what is vertical bargaining (which means it is less subject to specific conditions threatening to violate the underlying assumptions, the 'rules' of the game). In consequence it is important to understand how customers can 'induce' competition among suppliers. ${ }^{5}$ Another piece of writing in the same vein is that of Snyder (1996) who erects a model in the guise of 'an infinitely repeated procurement auction' wherein the potential for suppliers to 
collude (competition being curtailed) stems from customer characteristics. As the buyer here is presumed to be able to act autonomously via its own purchasing pattern there is a more or less direct vertical impact on horizontal competition. That is to say, there is a continuous stream of 'consumption opportunities' that face the buyer who is in the position to postpone the placing of orders until a mass thereof is accumulated 'in-house'. Only then does the customer approach the supply market, equipped with a considerable amount of buying power. In consequence the customer is able to derive a lower price in the form of major volume discounts, something which counterbalances any collusive attempts from suppliers. And a mere threat in this direction is enough to induce sellers to quote more 'competitive' (lower) prices (confer Baumol et al.'s 1988 reasoning on market contestability). A similar effect is at hand when buyers are able to act in concert, something allegedly being the case with skiers who buy lift tickets through alpine clubs and similar. ${ }^{6}$

\section{Austrians and Customer Impact on Competition}

It is hardly very bold to state that some works of Israel Kirzner epitomize what most would accept as fairly well representing the contemporary mainstream of Austrian economics. This is an Austrian 'intermediate position' (Kirzner 1992:3-4)) that conceives of market order as relevant but not eternal, midway between conventional equilibrium economics and facets of radical subjectivism. ${ }^{7}$ In this way it also embodies the market process edifice once erected by Mises and Hayek. Such an Austrian market dictum is much inspired by the former's view of the market as an entrepreneurially driven process and the latter's pinpointing of knowledge as the very propelling force of such dynamics (Kirzner 1997:67). Given such dynamics full market order cannot ever be, but only entrepreneurial action that improves plan coordination in this direction. A most processual perspective on competition follows suit.

The well-known position of Kirzner tells about the market as 'driven' by 'entrepreneurial boldness and imagination' and 'constituted' by 'the series of discoveries generated by that entrepreneurial boldness and alertness' (Kirzner 1997:73). This alertness represents what is entrepreneurial in human action and is made up by a particular inclination to see what others do not see. And such ignorance of others concerning market opportunities constitutes the very scope of alertness which is market profit. A few core market assumptions furthermore constitute the sounding board devoid of which this dynamic view cannot work out (Kirzner 1992:38-39, 42). Firstly, the market is always in a state of flux. Secondly, there are two major facets of market alterations, 'structural' exogenous ones and endogenous change that follows from the interplay of human action in supply and demand. Whereas the former implies variations in so-called underlying variables (for instance preferences and technology) the latter stems from revised 'induced variables' such as production methods, prices, product qualities and quantities decided upon by market actors. And there is only a loose coupling between the two (whereas conventional equilibrium analysis would say that endogenous change is fully determined by exogenous ditto). Price (although reflecting technology and preferences) is then deliberately decided upon in market process theory whereas it is merely parametric in the conventional agenda. Thirdly, for the corresponding dynamics to work out there is one fundamental prerequisite, that of free market entry. This 
prerequisite is also the backbone of the resulting view of competition as a discovery procedure subject to the entrepreneurial element of human action. The tight linkage with the market is obvious as once again there is a delicate interplay between the areas of knowledge and entrepreneurship.

Take knowledge first. It matters since it is others' lack of insight regarding market opportunities, their ignorance, which manifests the scope for entrepreneurial profit. In this Austrian guise it is not really scarce in the conventional sense of the word since scarcity means that one is informed about the knowledge that one misses out on. To possess knowledge is instead to experience relatively less market ignorance than others. What renders such knowledge different is its originating not in deliberate search but in discovery with coordinative implications. It cannot furthermore ever be perfect, or imperfect, with reference to some distinguished facts, eventually-to-be-revealed. We do not know what we do not know. But some of us are, somehow, in a better position than others to find out by discovering hitherto unnoticed profit opportunities. ${ }^{8}$ This Kirzner's stance on knowledge as discovery via alertness, endemic to 'equilibration without equilibrium', is midway between the two positions of knowledge as 'perfect' (the outcome of deliberate search) and pure luck (Kirzner 1992:4-5, 46, 48). ${ }^{9}$

What distinguishes discovery (relevant to hitherto unknown profit opportunities) from successful search (relevant to the deliberate production of information which one knew one had lacked) is that the former (unlike the latter) involves that surprise which accompanies the realization that one had overlooked something in fact readily available. ... This feature of discovery characterizes the entrepreneurial process of the equilibrating market. What accounts for a systematic tendency toward that succession of wholesome surprises which must constitute the equilibrative process, is not any implausible series of happy accidents, but rather the natural alertness ... to possible opportunities (or the danger of possible disaster) which is characteristic of human beings. ${ }^{10}$

Then take entrepreneurship. This is a unique feature of human action that makes discovery come true. It always means striving for efficiency within a given means-ends framework, but in addition to that to be entrepreneurial entails the very creation and interpretation of the means-ends framework itself. And this latter is the truly crucial aspect. Entrepreneurial action hence entails some deliberation over market opportunities following human judgment, and not only speculation as pure windfall luck would in no way be coherent with improved market coordination (Kirzner 1973:31, 33-34, 36, 86). ${ }^{11}$ Since these opportunities (given the account of knowledge provided above) are not given, but discovered as a consequence of alertness, market entrepreneurship entails judging non-obvious potentials for market arbitrage. 'The profit-grasping actions of entrepreneurs dispel the ignorance which was responsible for the profit opportunities, and thus generate a tendency towards coordination among market decisions' (Kirzner 1992:12). But whereas entrepreneurship is akin to action, seen as the formulation of plans and the subsequent alterations thereof, alertness is different. This constitutes the micro-foundation of entrepreneurship since 'alertness ... [is] the propensity to see, discover, market (profit) opportunities' which only subsequently can be acted upon as the creation of new means-ends frameworks by way of market experience 
gained. So whereas entrepreneurship (a generic dimension of human action) serves as the lubricant of the market system, it is alertness (an individual propensity that for some reason accrues only to some) that fuels it in the direction towards equilibrium as actor plan coordination is improved.

The ensuing view of competition resides firmly in the above account of the market process. Competition is a discovery procedure. It arises for market opportunities and the outcome is subject to alertness that resides with entrepreneurs who are able to freely move into the market. ${ }^{12}$ Devoid of the opportunity for entry, eventually resulting in profits, there is simply no scope for alertness as there is nothing (no profit opportunity) that can 'switch it on'. This makes competition necessarily both actual and potential, something implying that not only is there competition between those already in the market but they also constantly face the threat from outside by potential new entrants (Kirzner 1973:98, Baumol et al. 1988). Actual competition in isolation among incumbents then cannot really be competition. The twist of the argument is however the intertwined nature of competition and entrepreneurship. They are mutually dependent as one cannot exist without the other and in consequence 'entrepreneurial activity is always competitive and ... competitive activity is always entrepreneurial' (Kirzner 1973:16-17, 94). The discovery procedure of competition is embodied in alertness as market opportunities, not seen by all, are realized. This is discerned as the 'eagerness' of market actors to buy and sell which is communicated to other market participants by way of pricing and plans as to quality et cetera. These communicated plans make up an entrepreneurial space wherein only in retrospect distinct patterns can be discerned as competition between entrepreneurs (Kirzner 1973:15, 1997:73). As opposed to the conventional view of competition, this dynamic conception entails that market actors themselves constitute the market forces via their planned and realized conduct. They are not 'takers', but 'makers' of price, quality and an array of other things. Their behaviors are the equilibrating tendencies of the market (Kirzner 1973:13, 1997:64, 69).

The customer enters the Austrian discourse on competition via Mises' ideas on consumer sovereignty that mirrors his overall concern with the market as a 'social body'. Supply is always subject to, and conditioned by, demand. This is a genuinely Austrian position and yet another instance where it stands well out from the economics mainstream. The most articulated social aspect in the argument is that competition assigns 'social positions.' To buy or not to buy from one or the other is decisive for the way in which potential suppliers will find themselves in the social arena and this comes about by way of competition as induced by consumers. And this means that freedom of market entry ( $=$ the occupation of a social position) is subject to the discretionary choice of consumers in their deliberation eventually to opt for new sources of supply. 'Entrance into a definite branch of industry is virtually free to newcomers only as far as the consumers approve of this branch's expansion or as far as the newcomers succeed in supplanting those already occupied in it by filling better or more cheaply the demands of the consumers' (Mises 1963 [1949]:275). As noted in the opening of the paper the notion of consumer sovereignty originates with the works of Hutt (1940) who claims it lays bare what is seldom articulated in the economics discourse, thus emphasizing 'the controlling power exercised by free individuals' in their choosing between ends when resources are scarce. That is to say, by choosing what to consume, and 
from whom to acquire it, the consumer draws upon the means provided by suppliers and thus let her will come true.

This crucial though still not very salient observation by Mises is partly mirrored in the reasoning proposed by Kirzner 1973:44-45, 180-186). His argument rests upon the assumed symmetry between entrepreneurship in the demand and in the supply markets. That is to say, one can exert entrepreneurship not only towards customers, but also towards suppliers. Customer entrepreneurship enters the stage. The coordination of activities in supply ('buying resources') and demand ('selling products') markets then constitutes an often overlooked entrepreneurial opportunity. In consequence, the more external resources that are relied upon in the supply market, the more of pure entrepreneurial scope is around in the sense that the more 'brokerage' can be undertaken (Kirzner 1973:45).

His [the customer's] buying effort has succeeded in entrepreneurially 'differentiating' that which he buys, in exactly the same manner as [a] selling effort 'differentiates' entrepreneurially that which a producer offers for sale... It turns out, we have discovered, that the entrepreneur's role as buyer in the factor market is wholly symmetrical with his role as seller in the product market. ... The entrepreneur-producer discovers that in this way he can simultaneously offer opportunities in the factor market and in the product market, at terms that leave him with a profit. ... In the factor market, too, the entrepreneur's function must surely include making factor owners aware of the opportunities to sell which he is prepared to offer them. Thus there is nothing so far to suggest that buying effort by entrepreneurs-producers should necessarily be less vigorous than their selling effort. ${ }^{13}$

That is to say, by acting in an entrepreneurial way 'vertically', in buying in a certain manner, the customer-entrepreneur is in the position to influence the way in which suppliersentrepreneurs relate to each other. Not only does customer entrepreneurship then entail immediate advantages as enjoyed by the buyer but also, by drawing on market opportunities, it constitutes a crucial impetus for market dynamics - competition.

\section{Georg Simmel and Tertius Gaudens}

As can be judged from above, there are signs of customer impact on competition both within neoclassical and Austrian economics. In the former this is very much associated with the notion of market power and to a certain extent with auction theory, in particular as framed via games. Austrians are in general closer to a demand-inclined understanding of market phenomena which puts them in a more comfortable seat when it comes to framing how competition could in fact be subject to customer influence. Such an endeavor obviously depends very much on how competition as such is treated. And the full-fledged manner in which Austrian ideas shoulder this challenge, that by far outperform the rather empty neoclassical account in this regard, adds to this impression. This process-oriented view of competition homes in on demand impact in two major ways. The Misesian argument teaches that it is the customer who is the agent of free market entry by means of consumer sovereignty exerted as supply source selection. Its complementary Kirznerian view stresses that the 
customer, by distinguishing between suppliers, could in fact exert entrepreneurship in the supply market. This affirms the close affinity between competition and entrepreneurship as suggested by Austrians. Notwithstanding the merits of these accounts on competition it is still obvious that they do not start out in scrutinizing the very nature of customer impact. They have got other points of entrance although such demand-influence is noticed but not really further elaborated to an extent that would correspond to the potential value thereof. It is crucial to go elsewhere. By means of some early Austrian writings.

As observed by Laidler and Rowe (1980) Georg Simmel is one of the many social scientists that at the turn of the century let themselves be inspired by the works of Carl Menger. This is seen especially in Simmel's account of monetary theory where the Austrian legacy is obvious through the role of money as a spontaneous institution. There also seems to have been quite some influence the other way around, although not explicit, in that Simmelian ideas are found in the works of both Mises and Hayek. His much limited impact on economics at large can thus only be attributed to the ignorance mostly experienced also by the Austrian school. But not only monetary theory, but market thinking at large, can benefit from Simmel, although in a more subtle manner. ${ }^{14}$ Unlike Weber, his fellow contemporary colleague of sociology who spends considerable efforts in trying to join the forces of economics and sociology (confer Swedberg 1998), Simmel does not pay very much attention to the market institution. But he does indulge in a scrutiny of group dynamics, and in combination with the issue of conflict this is also his entry into competition. Exchange is obviously a central feature here and in particular the economic facet thereof since this embodies 'complete' reciprocity, one of the four main social principles according to Simmel (confer Levine 1971:xxxiii-xxxiv). ${ }^{15}$

Before looking somewhat more into how conflict and small-group dynamics are instrumental for the unfolding of rivalry it is however necessary to briefly have a glimpse at how Simmel (1955 [1908]:57 ff) unravels some fundamental properties of competition. He comes up with three somewhat interrelated aspects thereof.

1. Competition is manifest as the subjective goal of the competitor is intertwined with the objective outcome for others. This property entails that the benefits resulting from competition do not primarily accrue to the contestants themselves but to others. It follows that this 'prize' then cannot ever be the goal of their opposed strivings. To provoke someone's defeat in this regard carries no value whatsoever in isolation. 'The businessman who succeeds in having his competitor suspected of unsoundness by the public gains nothing if the public's needs are suddenly deflected from his merchandise.' The subjective motives of a business - to outperform others, and the objective social values attained - public at large paying less, are in consequence related in the most particular fashion.

2. The objective of competition is to gain the relative favor of a third party. Following the above a competitor focuses upon the benefits eventually enjoyed by those 'outside'. If not there is pure conflict. The strategy adopted is to get as 'close as possible' to the third benefiting party and thereby to outperform any rivals, something eventually embodied in the successful creation of a relationship between (for instance) a seller and a buyer. This 'sharpens the businessman's sensitivity to the tendencies of the public' which means that 
customer preferences always must be what matter most, 'the adaptation of the producers to the consumers'.

3. All competitive success can only be understood in relation to the failure of fellow competitors. Absolute and relative success is connected. That is to say, what one businessman succeeds in doing in the marketplace is always mirrored in what someone else falls short of performing.

In this particular sociological discourse conflict is a natural thing that brings with it nondisruptive change, very much in contrast to the destructive and opposing elements thereof as proposed by Marx (Turner 1991:189-195). Conflict prevails in the interest of unity given a certain unfolding tension. It is there 'to resolve divergent dualisms' (Simmel 1955 [1908]:13 ff). A most visible example thereof is the case of competition, a particular kind of conflict where a seemingly rough striving among individuals entails societal benefits. To home in on such competition it is however necessary to consider Simmel's fascination for small-group dynamics. And as the consequences of a group drop-out are so devastating, and following the role of intimacy, the properties of the dyad (die Zweiverbindung) stands out in relation to other such small groups (Simmel 1950 [1908]:125 ff). But it is in the transformation of the dyad into the triad, by the intrusion of a new actor, that the dynamics from a competition perspective get really intriguing. ${ }^{16}$ As this occurs the third party is in the position to have both uniting and/or separating impact on the two others. That is to say, when a three-party microstructure is considered the relation between any two of them will necessarily be subject to the presence of the 'third' party via the indirect connection that this party constitutes. A direct tie is then conditioned, strengthened and/or weakened accordingly. It is in fact viable, asserts Simmel, to interpret a triad as variable 'parties of two' that in concert turn against the residual party who however in a similar manner can play these two out against one another.

As the triad, die Verbindung zu dreien itself is scrutinized, Simmel (1950 [1908]:145154) notes that by introducing a third party to a dyad the absolute contrast that resides between two actors is subject to 'transition, conciliation and abandonment'. This obviously implies fundamental consequences for the way in which any two actors relate to one another. Simmel distinguishes three types of group formations that can be found in a triadic structure following the role of an intrusive third element.

1. The Invisible Third and The Non-Partisan/The Mediator. In this constellation there is on the one hand possibly quite some distance between the two and the third, and it follows that interactions can be interpreted in 'isolated dyads' within the triad. On the other hand there could be more compelling cases as that of a monogamous marriage welcoming a baby, the advent of whom might increase the strength (of love or similar) directly or indirectly between the spouses. A yet more explicit effect that pertains to the issue of conflict is that of a 'non-partisan/mediator' who balances the two other parties by making concord between them come by. The third then interferes and pushes the other two closer together merely by relating certain obvious facts that are made more objective and explicit than they seemed to be before. The Mediator does not interfere with the facts, but makes the arguments 'pure' by depriving them of hazardous affection. In this 
role the third must necessiraly either 'stand above' the combatants, or be as involved with both of the conflicting parties.

2. The Arbitrator. The foremost difference between an arbitrator and a mediator is that the former actively frames the outcome of the conflict whereas the latter only watches the parties' own conflict resolution. 'They [the parties] project ... their will to conciliation, and this will becomes personified in the arbitrator'. Both parties must actively search for the help of The Arbitrator and agree thereupon (if on nothing else), thus sustaining the group. Subsequently The Arbitrator actively interferes with the conflict and reshapes the views held by the two parties in order to make more of a mutual perspective come forward.

3. Tertius Gaudens. ${ }^{17}$ The Tertius Gaudens is the most distinctive of Simmel's third element roles and this is where his argument on competition as an indirect conflict is advanced. Until now, The Mediator/The Arbitrator draws on her impartiality in order to support the group in making it live on by means of reducing the level of conflict to be found between the two other parties. In so acting 'Tertius' however serves her own egotistic interests by 'brokering' the conflict between the two. This agency produces some very unstable interaction that ultimately threatens the very existence of the group. An example furthered (Simmel 1950 [1908]:141) pertains to the labor market and the situation between a superordinate and his subordinates (as distinguished from when there is only one subordinate). 'He who has one child is his slave; he who has more is their master.'

This notion of Tertius is the epitome of Simmel's reasoning on the very nature of competition as an indirect kind of conflict where the customer in consequence is instrumental for making it come by. This customer agency of 'competition invocation' is elaborated upon by Simmel and on this occasion he also specifies further how Tertius works out in a business context. 'In economics, the third party is the consumer ... [something mirroring] business competition for the consumer ... the net effect [of which] is the benefit of ... [this] third party (Simmel 1955 [1908]:77, 59).

A Tertius could furthermore take on either a passive or an active guise (Simmel 1950 [1908]:154ff). A passive third party is someone who exposes herself to the disunion of the two others and thereby is in the position to reap the resulting benefits from this tension that originates either in them controlling each other or in one of them granting Tertius explicit favors. The active Tertius is different. In that case the deliberate invocation of competitive tension could come by in one of two ways. Either there is already some hostility present between the two that is pulled out in the light and thus exploited by the third. Or this hostility does not really prevail but emerges as Tertius lays bare the hostility which 'should' be there by rendering them more interdependent. The former alternative is found as two coexisting competing suppliers suddenly are made closer to each other as their common customer declares that from now on one of them will receive the vast majority of orders and the other one will receive much less. In the latter case a customer makes two parallel suppliers aware of each other by declaring that from now on they shall have to bid for each individual order, and eventually this bidding could be made very open.

On the largest scale, the tertius gaudens is represented by the buying public in an economy with free competition. The fight among the producers for the buyer makes 
the buyer almost completely independent of the individual supplier. He is, however, completely dependent on their totality; and their coalition would, in fact, at once invert the relationship [that is, by way of collusion] ... These situations of tertius gaudens may be arranged along a continuum. At the one end, perhaps, is the above-mentioned case of the woman between two suitors. Here the decision depends on the two men's natures, rather than on any of their activities. The chooser, therefore, usually makes no conditions and thus does not fully exploit the situation. At the other end, there is the situation which gives the tertius gaudens his extreme advantage. It is found in [a] modern market economy with its complete exclusion of the personal element: here the advantage of the chooser reaches a point where the parties relieve him of the maximum intensification of his own bargaining condition....

That is to say, the more socially and affectively detached Tertius is, the easier it is to derive benefits as one could act by not being very much conditioned by the particular context at hand. And, adds Simmel (1950 [1908]:160-162), the more volatile, overt, and emotionladen the tension between the two, the greater is the potential for Tertius, in particular as she herself is in a stable and intellectually controllable position.

As will be further explored right below when the significance of Simmel's reasoning for economics is considered this particular aspect of the argument, in the following labeled supplier specificity (thus mirroring market intimacy), is what conditions the impact from Tertius on competition. It is then viable to foreshadow a market continuum along low and high supplier specificity where the anonymity of the former and the intimacy of the latter will be decisive for the Tertius agency, that is to say the entrepreneurial scope at hand. Such specificity can then be seen as a buyer's institutional context of choice between alternative sources of supply.

\section{On the Institutional Context of Customer Entrepreneurship}

The above reasoning delineates the manner in which Simmel, by means of the Tertius Gaudens principle for group formation, brings forward an argument for how customers exercise market entrepreneurship. The claim of this paper is that these ideas, notwithstanding the meritorious efforts in the same vein by Hutt, Mises, Galbraith and others, manage to mitigate much of the shortcomings of economics concerning the much overlooked instrumental role of customers for competition. As foreshadowed above it is also possible, along Simmel's reasoning on '[t]hese situations of tertius gaudens', to frame the institutional setting of choice according to the degree of 'exclusion of the personal element'. Such a market setting can then be characterized by intimacy or anonymity following the degree of supplier specificity that hence conditions the working-out of customer entrepreneurship and in consequence competition. This institutional turn of the argument is akin to that proposed by Koppl (2002) as regards 'Big Players' and their impact on the formation of market expectations. Such a market player is the nexus of agency as discerned via the discretionary use of power that influences the market process and an insusceptibility to the competitive forces to be found therein. Sometimes privileged Big Players could (something however not specified by Koppl) emerge as customers who use their power to impact the market by thwarting 
the reliability of market expectations formation to their own benefit. Attention switches from narrow economic data, the 'fundamentals', to what is by definition unpredictable, such as immediate policy impact and the possible action pattern of Big Players themselves. 'Discretionary policymaking focuses entrepreneurial attention on the politics of the market. ... When discretionary policymaking thus reduces the knowability of markets and the reliability of expectations, it devalues skills and makes luck count for more' (Koppl 2002:121). The argument nicely manages to hint at a few points of interest regarding customer entrepreneurship that draw on its institutional meaning. According to Koppl (2002:121) the presence of Big Players and their exertion of market power thus 'creates a situation of open reflexivity [that frustrates coordination]' and proposes 'low anonymity' market conduct on behalf of others. This impacts competition.

... I identified two important conditions of market competition, namely, atomism and stability. When these conditions are violated, the filter of profit and loss is less likely to weed out unfit habits of action. It is less likely to weed out acognitive expectations that are not prescient. Big Players violate the condition of atomism. Thus, Big Players tend to corrupt acognitive expectations.... Big Players [furthermore] reduce the informational efficiency of markets by reducing the knowability of the future and by increasing the element of chance in determining who trades in the market. ${ }^{18}$

Two particular issues that mirror Koppl's reasoning will be discussed in the following.

1. To Koppl, the quintessential contribution to economics is about the formation of market expectations-where is this particular twist as customer entrepreneurship is brought up-how is the explanation of markets enhanced?

2. To Koppl, sheer size is conducive for market power and ensuing expectations impactbut what about market symmetry when size as such is not an issue-is not the supplier as much in the position to induce tension between customers, and in what way would this then affect the argument on customer entrepreneurship?

If now customer entrepreneurship induces competition among sellers via the principle of Tertius Gaudens, how does this actually come by in a manner that improves our understanding for the market process? The argument to be furthered here, much in line with the ideas of Gualerzi (1998) on consumer agency and those of Koppl (2002) on the formation of (subjective) expectations towards powerful actors, is that it is the institutional context of choice that matters. Such a contextual frame is here depicted as supplier specificity that tells about the extent to which intimacy and/or anonymity characterizes the market under scrutiny. This specificity could be depicted in a variety of ways and portrayed as either high or low. Whereas the former, implying market intimacy, reduces the scope for customer entrepreneurship to work, this scope is enhanced when market anonymity prevails as supplier specificity is low. This specificity argument is akin to the reasoning from within new institutional economics according to which transaction costs are subject to the degree of specificity to which resources are put (confer Williamson 1987). A high level of site/physical 
asset/human asset/dedicated asset specificity means that the very identity of the customer in relation to a specific supplier impacts the costs endemic to market exchange. To break a prevailing supplier relationship which means a high level of supplier specificity can thus be costly in terms of resource deployment as exchange economics of scale and scope vanish. 'Difficulty in turning to others increases the probability that present parties to a cooperative arrangement will attempt to take advantage of each other if the future unfolds in a way that makes this possible. ... Competition [thus] loses some of its disciplining force because transactor-specific assets suffer a reduction in their value if new transactors are turned to in substitution for those for whom the assets were designed' (Demsetz 1992:25).

As seen in the last sentence of the lengthy quote above the idea of supplier specificity is easily discernible also at the core of the Tertius Gaudens argument. Simmel however chooses to depict such specificity in terms of general social traits such as the 'personal element' as seen in someone's 'nature'. It is hence the identity of the suppliers, here discerned as supplier specificity, that tells whether there is in fact any scope for customer entrepreneurship to work out and thus induce competition among sellers. Consider for instance how Simmel (1955 [1908]:61, 64) depicts the manner in which suppliers try to outperform one another by getting as close to the buyer as possible, something undertaken via the establishing of relationships, the consequence of which is that supplier specificity increases and the cost of switching suppliers likewise goes up.

Competition compels the wooer who has a co-wooer, and often in this way alone comes to be a wooer properly speaking, to go out to the wooed, come close to him, establish ties with him, find his strengths and weaknesses and adjust to them, find all bridges, or cast new ones, which might connect the competitor's own being and doing with his. ... To be sure, in ... [competition], a man fights another man, but for a third one. And the winning over of that third one can be achieved in a thousand ways only through the sociological means of persuasion or conviction, surpassing or underselling, suggestion or threat, in short, through psychological connection. But just as often, this winning over also means in its effect such a psychological connection, the founding of a relationship-from the momentary relation established by a purchase in a store to marriage.

This is the epitome of what currently is experienced in everyday markets as suppliers' efforts to home in on buyers via so-called relationship marketing, conscious efforts to establish more or less exclusionary ties with their customers. 'It follows that the new competitive environment implies a closer monitoring of the market and a deeper involvement of consumers. Consumers' contributions become more important because the very logic of the global economy makes them both more informed and more demanding. ... In the new competitive environment the consumer is increasingly an interactive agent, responding to and modifying the stimuli coming from firms' productive and marketing strategies.... This clarifies further the sense in which we can think of the consumer as an active agent' (Gualerzi 1998:58, 59). Market communications are then no longer about trivial anonymous calls to the mass as traditionally experienced in market economies. Instead personalized calls are put to the fore as customized offers are being designed (confer Peppers and Rodgers 1997). 
This eventually results in the establishing of bonds that could be of various kinds. Whereas economic bonds stem from incentive-based pricing schemes, technical dittos might be found in the particular way of communication and distribution (confer Hammarkvist et al. 1982). Yet an example is how the forming of social bonds epitomizes what by some is labeled social capital, patterns of exchange relationships that embody enacted expectations of trust and obligations that originate in reciprocity norms (confer Bourdieu 1980, Coleman 1988, Woolcock 1998). ${ }^{19}$ The particularity of social capital in this context is also at the very heart of Burt's (1992) argument on so-called structural holes that nicely fits the idea of Tertius Gaudens into Kirzner's turn on entrepreneurship (see further below).

The above reasoning is in the position to benefit economics in two major ways. Firstly, by bringing forward how customer entrepreneurship impacts the market process given certain institutional characteristics, more is learned about the conditioning of market agency. This holds in particular as regards the social features of exchange as supplier specificity, something brought up in the discourse on social capital as discussed by Burt (1992) and others. Secondly, economics hereby is in the position to shoulder some challenges concerning the understanding of how markets evolve from mass markets characterized by anonymity to nexus of relationships where market intimacy prevails to an extent not experienced before. As quite some paradox the potential for customer entrepreneurship is in consequence altered, and this in an era of time where the 'free' choice of consumers is more salient than ever in the societal discourse.

The next substantial question mark surrounding the argument as put forward here pertains to the issue of symmetry between supply and demand in acting as Tertius Gaudens. If now buyers are in the position to invoke tension between sellers, why not the other way around, in particular as monopoly and oligopoly find their ways across markets? There are two main ways of shouldering this question. The first one simply argues that markets are in general more characterized by over-supply than over-demand which means that overall competition among sellers is on the increase relative to that between buyers (confer D' Aveni 1994). Resorting to social exchange theory and its dictum of power-dependence relationship imbalances it is hence viable to argue that sellers, in cases of market intimacy, are on average more dependent on buyers than the other way around (confer Emerson 1962). This is so since the latter, even though appreciating the exchange, have got more of a discretionary choice than the other way around. It means customers are in the position to exert their power, as framed by the idea of Tertius Gaudens. The second way of shouldering the issue of symmetry is slightly more sophisticated in all its simplicity and owes its debt to Hutt (1940) and his argument on consumer sovereignty.

All effective choice between [demand-induced] ends of this nature by free individuals is a manifestation of consumer's sovereignty; just a choice between means is, under my terminology, a manifestation of producer's discretion.... When ends are being chosen, we are concerned with demand; when means are being chosen, we are concerned with an aspect of supply... ${ }^{20}$

That is to say, once we treat the market process as ultimately governed by preferences and adjacent choices of ends to which scarce means subsequently are put (hardly a very controversial position), the discretionary choice of suppliers cannot be. Such producer's 
choice can only prevail subject to demand and can in consequence hardly be sovereign as it is not free but only constrained by customers via their freedom of choice following prevailing preference patterns.

\section{An Austrian Tertius Gaudens?}

In the above, it is shown that there are indications of customer impact in the Austrian discourse on competition but these remain largely unexploited given a host of other preoccupations for this market process scrutiny. This paper has it that such signs could in fact be elaborated upon, much to the benefit of the Austrian agenda as a whole, by drawing on the reasoning on Tertius Gaudens as pursued by Simmel. This would provide yet another fertile conceptual soil for market process theory and economics at large, in particular concerning how institutional features of market anonymity and intimacy impact entrepreneurial agency. Apart from the mere intuitive noticing of the customer in this respect there are a few other reasons that motivate this stance taken, such as the social inclination of Austrian economics and the entrepreneurial nature of Tertius Gaudens. These will be somewhat explored in this final section of the paper that also puts on stage some ideas of an Austrian Tertius as a manifest of how competition is subject to both hampering and promoting customer impact, something illustrated by what is really new for economics in all of this. A similar argument from economic sociology however deserves some attention at first.

This tying-together of the 'Austrian' and the 'Simmelian' as Tertius Gaudens is, as already alluded to elsewhere, brought forward by Ronald Burt (1992:274) in his endeavor of constructing a sociological model of competition. 'There is a distinct quality of the tertius in Kirzner's successful entrepreneur...' What Burt sets out do to is to provide an argument where an entrepreneur who manages to draw on the social context stands to be profitable as market opportunities discerned as missing social ties (the source of social capital) are discovered by spanning gaps between actors previously not connected. The entrepreneurial agency consists of brokering what Burt calls structural holes - what is the marginal impact of new contacts? The value of adding a new direct contact to one's network is subject to whether this new tie marginally adds brand new indirect contacts or only constitutes an alternative path to contacts already enjoyed. To carry potential 'spanning value' as a social hole, contacts should be redundant which means that they are neither tied directly to each other, nor do they have similar connections to other parts of the network. The reasoning originates in the notions of structural equivalence and autonomy. To be equivalent with someone means to have similar ties to the (market) environment whereas the degree of structural autonomy refers the extent to which other actors are unable to constrain one's own desired action pattern. An autonomous actor is able to control the environment by enjoying relative freedom in promoting its own interests, something at hand for a monopolist or a monopsonist. To be autonomous means to have few structural holes around oneself (thus others cannot bridge any unfulfilled ties) but plenty thereof around others (thus opening up for the prospect of social entrepreneurial bridging). What makes a difference is not what actually prevails, but what is currently absent, an argument that originates in Granovetter's (1973) reasoning on the 'strength of weak ties'. In consequence it is the absence, and not the prevalence of ties that constitutes (the value of) social capital as an opportunity 
for entrepreneurship that arises from the thus presence of information and control market benefits (Burt 1997:340).

The structural hole argument defines social capital in terms of the information and control advantages of being the broker in relations between people otherwise disconnected in social structure. ... The structural hole is an opportunity to broker the flow of information between people and control the form of projects that bring together people from opposite sides of the hole.

After this detour, now consider how Austrians could draw on Simmel, something thus elaborating upon the allusion made by Burt. Take customer impact first. The general Austrian concern with demand-side economics ties nicely to Simmel's observation that what renders competition different from conflict is its indirectness, meaning that the customer matters. Competition then results from customer impact that propels entrepreneurship and in consequence the market process. This agency can be deconstructed as follows. Mises teaches that consumer sovereignty spurs free market entry that according to Kirzner is the one key prerequisite for competition to unfold. And such agency serves to differentiate suppliers one from the other. How is it that this particular Austrian agency can accommodate Tertius Gaudens? As shown there are a few competition principles in the world of Tertius. These state that the subjective aspiration of a supplier (to have customers buy) results in buyers (society at large) enjoying benefits as discerned in lower prices and a vaster choice of offers. Suppliers are furthermore most interdependent as regards the mutual relativism of their success and set out to differentiate themselves by getting as close as possible to customers. This supplier aspiration is most endemic to the market process view wherein the successive formulation of plans in the aim of closing in with customers are at the fore. That is to say, competitors are not aimed at as such, but only market opportunities as residing with unsatisfied demand. So while the overall societal benefits of competitive rivalry is something which hardly sets Austrians in a special seat with regard to Simmel, their emphasis of striving for customer favor clearly does. The competitor-centric view of conventional economics is here far away. What then about competitor interdependence? Neoclassical economics at large argues that while sellers are competitor-centric they are nonetheless relatively independent in relation to one another which means they appear as faceless atoms. This is very far from the relative dependency that is discerned in Simmel's competition principles and in the reasoning of Mises according to which the competitive process is the assignment of social positions. To summarize, the emphasis of customer impact constitutes a firm bridging between Austrian thought and Simmel's ideas, something being in particular salient as the aim of suppliers and their relative mutual interdependence are concerned. Such bridging is also at hand when it comes to the meaning of relationships.

Now consider the social character of the reasoning. Mises (1963 [1949]) teaches that there are two main aspects of human action, social exchange and speculation. Whereas the second is what eventually will work out as entrepreneurship, the first (firmly anchored in the idea of reciprocity as intentional mutuality) is what makes action result in dependencies as the cement of the social web. 'Interpersonal exchange of goods and services weaves the bond which unites men into society. The societal formula is: do ut des.' This is why 
'[s]ociety is concerted action, cooperation' (Mises 1963 [1949]:143). For the argument here underway this is crucial since void of social meaning there is no way in which the agency of Tertius can work out, let alone be institutionally conditioned as framed here via supplier specificity. And this most social way of reasoning is inextricably linked to the market.

The market is a social body; it is the foremost social body. The market phenomena are social phenomena. They are the resultant of each individual's active contribution. ${ }^{21}$

As argued at some length elsewhere (confer Boettke 1998, Boettke and Storr 2000, Liljenberg 2001) there is plenty of evidence that ascertains this particular 'social' also from an Austrian angle. Apart from Mises' overall stance this is seen as institutions are discussed when the social relationships alluded to by Mises appear as uncertainty-reducing institutions- 'orientation maps' (confer Lachmann 1971:12-13, 49-50, O’Driscoll Jr and Rizzo 1996 [1985]:32). This furthermore ties nicely to Hayek's (1948 [1945, 1946]) view of knowledge as dispersed but instrumental for the spontaneous rise of social institutions, 'order', eventually appearing as relationships. These cannot ever be ex-ante designed but only the ex-post outcome of human action. The essence is that the social context matters primarily as a way of shouldering uncertainty as seen in reliance upon ties with those whom are known. ${ }^{22}$ As seen above such ties also explain the particular institutional circumstances at hand for customer entrepreneurship to work out as Tertius Gaudens.

The two affinities of customer impact and the social now established, look at how the two main micro-foundations of Tertius Gaudens, the active and the passive, associate with the Austrian argument in a most intriguing manner (confer Figure 1). Both of them converge on the realization of competition among suppliers via entrepreneurial customership. But they do so in two differing manners.

The first guise in which Tertius appears is as the 'active' who by various means invokes competition between suppliers. Competition is made come by through active involvement by a third intriguing party, for instance drawing upon the structural disunion between suppliers in rivalry. This is very much akin to the consumer sovereignty agency as expressed by Mises (1963 [1949]).

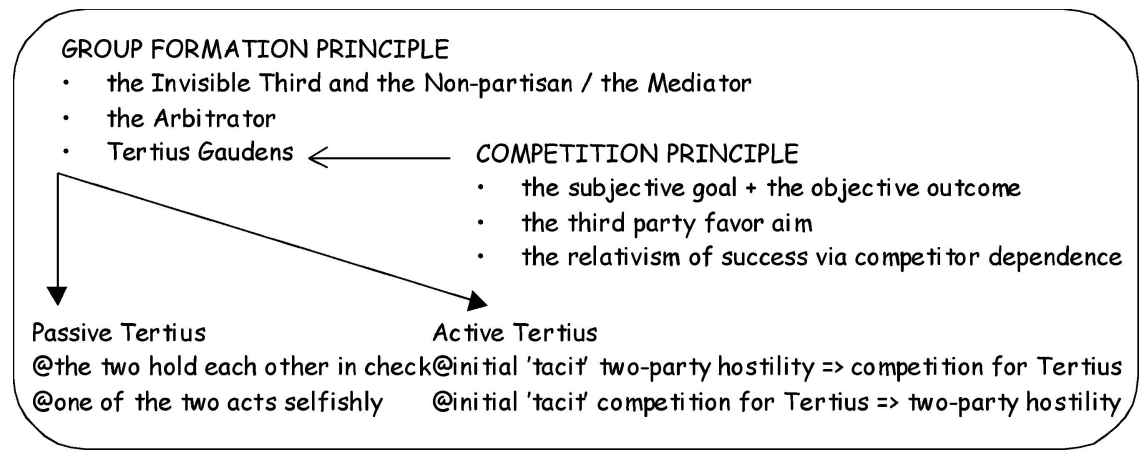

Figure 1. The role of the third and principles of competition according to Simmel. 
The direction of all economic affairs is in the market society a task of the entrepreneurs. ... [But,] [i]f a businessman does not strictly obey the orders of the public as they are conveyed to him by the structure of market prices, he suffers losses, he goes bankrupt, and is thus removed from his eminent position at the helm. Other men who did better in satisfying the demand of the consumers replace him.... [In this process, the consumers] are merciless bosses, full of whims and fancies, changeable and unpredictable. For them nothing counts other than their own satisfaction. They do not care a whit for past merit and vested interests.... Every penny spent has the power to work upon the production processes.... The decision of a consumer is carried into effect with the full momentum he gives it through his readiness to spend a definite amount of money. ${ }^{23}$

What happens is that the consumer takes on a most active role in thus 'assigning' social positions to sellers, be they incumbents or new entrants. And following the crucial role of free market entry for competition in the Austrian agenda, this is what makes it come by. The decision to buy or not from a particular source instantly and over time hence renders suppliers, that share a common customer, competitors. The argument naturally presupposes that sellers initially declare themselves ready in this regard so that the choice as exerted by the consumer has got a distinct discretionary character to it. The market can then be seen as made up of successive micro-triads where all pairs of potential suppliers are subject to consumer sovereignty. That is to say, each combination of a buyer and two suppliers striving for this customer, irrespective of whether they recognize one another or not, can be conceived of as the ideal-typical structural essence of Tertius Gaudens. In Simmel's words such Tertius agency invokes competition by eventually laying bare an already existing rivalry between suppliers (the case of informing them that by now choices-to-be-undertaken will be qualified via comparisons to an extent not known of before). Or, suppliers that were previously in the dark are simply made aware of one another. This 'active' Tertius, with a distinct affinity to Mises' consumer, is a bit different from its 'passive' and complementary counterpart, something discerned as Kirzner's ideas on alertness-inspired entrepreneurship. The point to be made here is that both guises of Tertius, the passive and the active, are in fact feasible in light of Austrian reasoning - something suggesting the coherence of ideas as argued for in this text.

To grasp the passive Tertius it is then necessary to consider entrepreneurship as formulated by Kirzner. In the market context of Simmel's this is the particular customer that exposes herself as a 'recipient' of the benefits that follow from the disunion of sellers. And by performing so this very customer does what others do not do, by seeing what others do not see, by being alert to market profit opportunities that others are ignorant about. This is a most reactive kind of entrepreneurship that puts Kirzner in a special position as regards the accommodation of the passive Tertius. As taught by Mises (1963 [1949]) entrepreneurship is the second aspect of human action next to social exchange and it goes beyond pure economizing behavior by not only encompassing efficiency in relation to given ends but also the very framing of means-ends structures themselves. To be entrepreneurial means to react upon market arbitrage opportunities that others do not perceive. Such opportunities are not created but enacted (Kirzner 1973, 1992). And this enactment can only come about following other's ignorance in perceiving the market opportunities which reside in unfulfilled demand. 
This reactive characteristic of entrepreneurship makes Kirzner an odd character when put beside others who are involved in the same discourse, such as Schumpeter.

Entrepreneurship is seen as the responding agency; the alertness of the entrepreneur to profit possibilities is seen as the social mechanism ensuring that society will capture the possibilities available to it. What the entrepreneurial element in individual decision making is to the individual, the entrepreneur is to the market economy. All this is missing in Schumpeter's scheme.... Aggressive, creative or other "Schumpeterian" characteristics often or typically displayed by successful real-world entrepreneurs, play no analytical role in the dynamically competitive market process driven by entrepreneurial activity. ${ }^{24}$

Such responding agency is motivated by the advent of alertness, the very core of entrepreneurship implying that an entrepreneur is 'not as a source of innovative ideas ex nihilo, but ...alert to the opportunities that exist already and are waiting to be noticed ... as responding to opportunities rather than creating them' (Kirzner 1973:74). It is 'the knowledge of sources of knowledge in terms of market data', 'the propensity to know where to look for information' (Kirzner 1973:67, 68). '[The] motivated propensity of man to formulate an image of the future'(Kirzner 1985:56). As seen this is akin to what Simmels is after, when two sellers allegedly control each other or one of them approaching Tertius who only reacts to such a move. Kirzner $(1985: 11,27)$ alleges that it is the opportunity of profit that 'switches on the alertness' just like an alarming device. But what this device really is remains unknown. 'We [simply] cannot explain how some men discover what is around the corner before others do' (Kirzner 1979:8).

Putting the above together means the realizing of an 'Austrian' Tertius that stands out in comparison to what is discerned until now in dynamic competition theory. Firstly, by recognizing and elaborating upon the kernels of already prevailing thought, Austrian competition theory takes a firm stance which fully recognizes the overall privilege of demand to the benefit of market process reasoning. Secondly, by laying bare also the social facet of market processing not only propelling but also impeding forces to competition are overtly paid attention to. The essence is that customer impact must always entail a balanced agency where entrepreneurship spurs, and social ties hinder, competition. As fully recognized above this is probably where the major impact of the argument for economics at large lie, the identification of market anonymity and intimacy as institutional features that conditions entrepreneurial agency. This social perspective hence recognizes the particular circumstances under which favoring customer impact works out in full. This occurs in a situation of market anonymity - low supplier specificity where the buyer is relatively 'detached' in a rationally stable position whereas sellers are emotionally involved as observed by Simmel. Thirdly, the active agency of Mises' consumer sovereignty and the passive ditto of Kirzner's customer alertness show how Simmel establishes the particular manner in which entrepreneurship ties to competition. By drawing on Tertius Gaudens, it is possible to reconcile these two stances and also to probe deeper into the very connection between competition and customer entrepreneurship. This points ahead towards an elaborated Austrian concept of competition and foreshadows more insight into market process complexity. 


\section{Acknowledgement}

This paper reflects the author's PhD project appearing as A Liljenberg 2001. Customergeared competition: A socio-Austrian explanation of Tertius Gaudens. Stockholm: The Economic Research Institute. Thee author is grateful for valuable comments received from two anonymous reviewers.

\section{Notes}

1. This paradox pillars the argument as put forward by Machovec (1995) regarding how the notion of perfect competition shoulders, or really does not shoulder, the quintessential of market dynamics. From a somewhat institutional perspective, and inspired by Buchanan, Machovec argues that ' $[\mathrm{t}] \mathrm{he}$ neoclassical emphasis on the mathematical conditions that accompany the end limit of competition deflected attention from the classical emphasis on the sociopolitical conditions needed to ensure the continuation of the process itself'.

2. With the advent of Knight's discourse on uncertainty the neoclassical notion of perfect competition reaches its peak refinement as a workable analytical tool (Stigler 1957:11-14, 1987:534). Knight (1921:76-80) lists eleven conditions of a so-called 'imaginary society' wherein complete freedom of exchange embodies the idea of perfect competition. (1) People are 'normal' as if being randomly chosen from 'a modern Western nation'. (2) These people are rational since they 'know what they want' and they 'seek it intelligently'. (3) People are furthermore free and in sole control of their 'own welfare and interests' as seen in the 'production, exchange, and consumption of goods.' (4) There prevails 'perfect mobility' in all respects of economic plans. 'The exchange of commodities must be virtually instantaneous and costless'. (5) Following 'perfect, continuous, costless intercommunication between all members of society', everyone has access to full market knowledge all the time. (6) People are fully independent from one another and 'act as individual[s] only'. There can be no collusion and '[e]xchange of finished goods is the only form of relation between individuals....' (7) Goods is exclusively acquired via 'free exchange in the open market' as 'fraud or deceit and theft' cannot be. (8) Division of labor applies in full so that only 'one single commodity' can be produced by each individual 'at any given time'. (9) Everything that matters analytically is static. 'All given factors and conditions are ... to remain absolutely unchanged.' (10) Production capacity is directly tied to separate individuals. (11) Any goods exchanged are finished products.

3. '[n analyzing an idealized economy (or market)] it is supposed, in the main, that there is perfect competition and that the choices of economic agents can be deduced from certain axioms of rationality' (Arrow and Hahn 1971:v).

4. 'One of the seemingly harmless simplifications of formal economic theory has been the assumption that producers of consumers' goods sell their products directly to consumers. ... In the typical modern market of few sellers, the active restraint is provided not by competitors but from the other side of the market by strong buyers. Given the convention against price competition, it is the role of the competitor that becomes passive in these markets. ... In the market of small numbers or oligopoly, the practical barriers to entry and the convention against price competition have eliminated the self-generating capacity of competition. The self-generating tendency of countervailing power, by contrast, is readily assimilated to the common sense of the situation and its existence ...' (Galbraith 1993 [1952]:117, 112, 114).

5. Confer Wilson (1977) for an elaborated case on the interplay between auction-like bidding and competition, and Bulow and Klemperer (1996) for the connection between monopoly and auction theory. These authors argue, just like McAfee and McMillan (1996), that under certain assumptions it is less important to be a good negotiator than to find some extra competition among sellers.

6. 'The results turn out to depend on three key variables. The usual results hold for the number of firms $\mathrm{N}$ and the discount factor $\delta$ : collusion becomes more difficult as $\mathrm{N}$ rises and $\delta$ falls. A new parameter is introduced, $\eta$, which measures the relative ease with which the buyer can transfer its consumption opportunities intertemporally. In general, $\eta$ is less than one, implying that the benefits from buying at the preferred time degrade with delay. The broad result is that as $\eta$ increases, the maximum collusive price falls. This result can be seen intuitively: the larger is $\eta$, the more valuable is any backlog of unfilled orders the buyer accumulates, 
ie, the larger is the endogenous "boom" in demand generated by the buyer. The sellers are forced to lower the collusive price to prevent undercutting' (Snyder 1996:749).

7. For an excellent account of a somewhat diverging Austrian perspective, that tends to pay more attention to disequilibration, and the role of institutions that condition equilibrium and unpredictable market-endogenous change, confer O’Driscoll Jr and Rizzo (1996 [1985]).

8. 'One is ignorant of the fact that there is a specific fact which one does not know' (Kirzner 1992:22).

9. 'Market coordination is not to be smuggled into economics by assumption; but neither is it to be peremptorily ruled out simply by referring to the uncertainty of the future.'

10. Kirzner (1997:72).

11. Kirzner (1973:84-87) takes some pains to acknowledge the Misesian thread that inspires him. Mises however emphasizes speculation as crucial for entrepreneurship whereas Kirzner underlines deliberate judgement of unnoticed profit opportunities.

12. 'Competition, in the process sense, is at least potentially present so long as there exist no arbitrary impediments to entry. So long as others are free to offer the most attractive opportunities they are aware of, no one is free from both the urge and the need to compete. Only when one is aware that others, despite the possibility of their offering something more attractive to the market, will be barred from doing so can one feel secure from competition. The competitive process depends entirely on the freedom of those with better ideas or with greater willingness to serve the market to offer better opportunities. Every arbitrary impediment to entry is a restriction on the competitiveness of the market process.... [As for a process view of competition] there can be no doubt that the necessary and sufficient condition for competition to exist without obstacle is complete freedom of entry into all kinds of market activity. When we assert that purely entrepreneurial activity is always competitive, we are then asserting that with respect to purely entrepreneurial activity no possible obstacles to freedom of entry can exist. ... [In sum,] ... [t]o induce dynamic entrepreneurial competition ... [Austrians] require the fulfillment of only one condition: guaranteeing free entrepreneurial entry into any market where profit opportunities may be perceived to exist (Kirzner 1973:97-99, 1997:74, added italics).

13. The first part of the argument relates the labor market but it is explicitly recognized that it pertains to 'any kind of buying effort' (Kirzner 1973:181-183).

14. So whereas Laidler and Rowe (1980) take on the 'Austrian Simmel' from a strict monetary angle this paper concentrates on how this connection benefits the understanding of markets via competition.

15. The others are 'form', distance', and 'dualism' (Levine 1971:xxxiii-xxxiv)).

16. The relative impact of yet other added actors can never approach what happens as the triad is formed.

17. As observed by Burt (1992:273) Simmel first draws on this phrase of Latin (literally the 'third benefiting [from the disunion of the two others]') in 1896 as he discusses the size of groups in the American Journal of Sociology. The etymological origins of Tertius Gaudens are however not easy to depict. It appears to be part of a longer expression, Duobus litigantibus tertius gaudet (literally 'as two are quarreling the third benefits'), and seems to be an anonymous proverb void of known originator. It might be a Latin translation from the Greek fables of Aesopos but this is far from certain (Aili 2003). The idea of Tertius Gaudens is lately put to use in the social sciences by Burt (1992) as he discusses the social structure of competition by means of so-called structural holes (see below in the main text). Others who use it are Callon (1998:9-10, as Burt is related to in the context of network agency) and Hedström and Swedberg (1998, p 5, as social mechanisms are discussed).

18. Koppl (2002:122).

19. For an extensive discussion of how social capital impacts competition, see Liljenberg (2001).

20. Hutt (1940:67).

21. Mises (1963 [1949]:315).

22. 'People with whom one expects to engage in one exchange per year may be of less importance to the success of one's plans than people with whom one trades every day' (O'Driscoll Jr and Rizzo 1996 [1985]:34).

23. Mises (1963 [1949]:269-270, 271).

24. Kirzner $(1979: 117,1998: 12,13)$. '[W]hile the opportunity to be discovered is often indeed the opportunity to be created, this truth should not obscure the more fundamental insight regarding entrepreneurship ... that for any entrepreneurial discovery creativity is never enough: it is necessary to recognize one's own creativity. In other words, an essential ingredient in each successful creative innovation is it's innovator's vision of what he can creatively accomplish' (Kirzner 1994:109). 


\section{References}

Aili, H. (2003) Personal Communication with Professor Hans Aili at the Department of Classical Languages of Stockholm University on August 21.

Arrow, K. J. and Hahn, F. H. (1971) General Competitive Analysis. San Francisco: Holden-Day.

Backhouse, R. E. (1990) “Competition.” In: Creedy, J. (Ed.). Foundations of Economic Thought. Oxford: Basil Blackwell.

Baumol, W. J., Panzar, J. C., and Willig, R. D. (1988) Contestable Markets And the Theory of Industry Structure. San Diego: Harcourt Brace Jovanovich, Publishers.

Bianchi, M. (1998a) “Opening \& Introduction.” In: Bianchi, M. (Ed.). The Active Consumer: Novelty and Surprise in Consumer Choice. London and New York: Routledge, pp. 1-18.

Bianchi, M. (1998b) "Taste for Novelty and Novel Tastes: The Role of Human Agency in Consumption." In: Bianchi, M. (Ed.). The Active Consumer: Novelty and Surprise in Consumer Choice. London and New York: Routledge, pp. 64-86.

Bourdieu, P. (1980) “Le Capital Social.” Actes de la Recherche en Sciences Sociales, 31: 2-3.

Blaug, M. (1997) Economic Theory in Retrospect. Cambridge: Cambridge University Press.

Boettke, P. J. (1998) "Rational Choice and Human Agency in Economics and Sociology: Exploring the WeberAustrian Connection.” In: Giersch, H. (Ed.). On the Merits and Limits of Markets. Berlin: Springer, pp. 53-81.

Boettke, P. J. and Storr, V. H. (2000) "Post Classical Political Economy: Polity, Society and Economy in Weber, Mises and Hayek." Paper Presented at the SCANCOR Workshop on Crossing Boundaries: Economics, Sociology and Organization Theory at Stanford University, September 30-October 1.

Bulow, J. and Klemperer, P. (1986) "Auctions Versus Negotiations." The American Economic Review, 86(1): 180-194.

Burt, R. S. (1992) Structural Holes: The Social Structure of Competition. Cambridge: Harvard University Press. Burt, R. S. (1997) “The Contingent Value of Social Capital.” Administrative Science Quarterly, 42: 339-365.

Callon, M. (1998) "Introduction: The Embeddedness of Economic Markets in Economics.” In: Callon, M. (Ed.), The Laws of the Markets. Oxford: Blackwell Publishers, pp. 1-57.

Chamberlin, E. H. [1969 (1933)]. The Theory of Monopolistic Competition: A Re-Orientation of the Theory of Value. Cambridge: Harvard, University Press.

Coleman, J. S. (1988) "Social Capital in the Creation of Human Capital.” American Journal of Sociology, 94(Supplement): 95-120.

D’Aveni, R. (1994) Hypercompetition: Managing the Dynamics of Strategic Maneuvring. New York: The Free Press.

Demsetz, H. (1982) “Economic, Legal and Political Dimensions of Competition.” In: F. de Vries (Ed.). Lectures in Economics. Amsterdam: North-Holland.

Demsetz, H. (1992) The Emerging Theory of the Firm. Uppsala: Uppsala Universitet.

Dennis, K. G. (1977) 'Competition' in the History of Economic Thought. New York: Arno Press.

Emerson, R. M. (1962) “Power-Dependence Relations.” American Sociological Review, 27: 31-41.

Friedman, M. (1953) Essays in Positive Economics. Chicago and London: The University of Chicago Press.

Galbraith, J. K. [1993 (1952)]. American Capitalism: The Concept of Countervailing Power. Oxford: Basil Blackwell.

Granovetter, M. (1973) “The Strength of Weak Ties.” American Journal of Sociology, 78(6): 1360-1380.

Gualerzi, D. (1998) “Economic Change, Choice and Innovation in Consumption.” In: Bianchi, M. (Ed.). The Active Consumer: Novelty and Surprise in Consumer Choice. London and New York: Routledge, pp. 46-63.

Hammarkvist, K.-O., Håkansson, H., and Mattsson, L.-G. (1982) Marknadsföring för Konkurrenskraft. Malmö: Liber Förlag.

Hayek, F. A. [1948 (1945)]. The Use of Knowledge in Society. Reprinted in Individualism and Economic Order, Chicago: The University of Chicago Press, pp. 77-91.

Hayek, F. A. [1948 (1946)] The Meaning of Competition. Reprinted in Individualism and Economic Order, Chicago: The University of Chicago Press, pp. 92-106.

Hedström, P. and Swedberg, R. (1998) "Social Mechanisms: An Introductory Essay." In: Hedström, P. and Swedberg, R. (Eds.). Social Mechanisms: An Analytical Approach to Social Theory. Cambridge: Cambridge University Press, pp. 1-31. 
Hutt, W. H. (1940) “The Concept of Consumers' Sovereignty.” Economic Journal, 49(March): 66-77.

Kirzner, I. M. (1973) Competition and Entrepreneurship. Chicago: The University of Chicago Press.

Kirzner, I. M. (1979) Perception, Opportunity, and Profit: Studies in the Theory of Entrepreneurship. Chicago:

The University of Chicago Press.

Kirzner, I. M. (1985) Discovery and the Capitalist Process. Chicago: The University of Chicago Press.

Kirzner, I. M. (1992) The Meaning of Market Process: Essays in the Development of Modern Austrian Economics. London: Routledge.

Kirzner, I. M. (1994) “Entrepreneurship.” In: Boettke, P. J. (Ed.). The Elgar Companion to Austrian Economics, Aldershot: Edward Elgar Publishing, pp. 103-110.

Kirzner, I. M. (1997) "Entrepreneurial Discovery and the Competitive Market Process: An Austrian Approach.” Journal of Economic Literature, 35: 60-85.

Kirzner, I. M. (1998) “Creativity and/or Alertness: A Reconsideration of the Schumpeterian Entrepreneur.” Paper presented at the Austrian Economics Colloquim, New York University, September 14.

Knight, F. (1921) Risk, Uncertainty and Profit. Boston and New York: Houghton Mifflin.

Koppl, R. (2002) Big Players and the Economic Theory of Expectations. Basingstoke and New York: Palgrave Macmillan.

Lachmann, L. M. (1971) The Legacy of Max Weber. Berkeley: The Glendessary Press.

Laidler, D. and Rowe, N. (1980) "Georg Simmel's Philosophy of Money: A Review Article for Economists." Journal of Economic Literature, XVIII (March): 97-105.

Levine, D. N. (1971) “Introduction.” In: Levine, D. N. (Ed.). Georg Simmel: On Individuality and Social Forms, Chicago: The University of Chicago Press, pp. ix-lxv.

Liljenberg, A. (2001) Customer-Geared Competition: A Socio-Austrian Explanation of Tertius Gaudens. Stockholm: The Economic Research Institute.

Machovec, F. M. (1995) Perfect Competition and the Transformation of Economics. London: Routledge.

Mandeville, B. [1970 (1705)]. The Fable of the Bees, or Private Vices, Public Benefits. London: Penguin Classics.

McAfee, R. P. and McMillan, J. (1996) "Competition and Game Theory." Journal of Market Research, XXXIII (August): 263-267.

McNulty, P. J. (1968) "Economic Theory and the Meaning of Competition." Quarterly Journal of Economics, 82: 639-656.

Mises, L. [1963 (1949)] Human Action: A Treatise on Economics. San Francisco: Fox \& Wilkes.

O’Driscoll Jr., G. P. and Rizzo, M. J. [1996 (1985)] The Economics of Time and Ignorance. London: Routledge.

Peppers, D. and Rogers, M. (1997) Enterprise one-to-one: Tools for Building Unbreakable Customer Relationships in the Interactive Age. New York: Doubleday.

Scherer, F. M. and Ross, D. (1990) Industrial Market Structure and Economic Performance. Boston: Houghton Mifflin.

Simmel, G. [1950 (1908)]. The Sociology of Georg Simmel. KH Wolff (ed \& trans). London: The Free Press of Glencoe.

Simmel, G. [1955 (1908)]. Conflict \& The Web of Group-Affiliations. KH Wolff and R Bendix (ed \& trans). New York: The Free Press.

Snyder, C. M. (1996) "A Dynamic Theory of Countervailing Power." Rand Journal of Economics, 27(4): 747-769.

Stigler, G. J. (1957) "Perfect Competition, Historically Contemplated." Journal of Political Economy, 65: 1-17.

Stigler, G. J. (1987) "Competition." In: Eatwell, J., Milgate, M., and Newman, P. (Eds.). The New Palgrave: A Dictionary of Economics. London: The Macmillan Press, pp. 531-535.

Swedberg, R. (1998) Max Weber and the Idea of Economic Sociology. Princeton: Princeton University Press.

Turner, J. (1991) The Structure of Sociological Theory. Belmont: Wadsworth.

Williamson, O. (1987) Antitrust Economics: Mergers, Contracting, and Strategic Behavior. Oxford: Basil Blackwell.

Wilson, R. (1977) “A Bidding Model of Perfect Competition.” Review of Economic Studies, 44: 511-518.

Woolcock, M. (1998) "Social Capital and Economic Development: Toward a Theoretical Synthesis and Policy

Framework." Theory and Society, 27:151-208.

Vickers, J. (1995) “Concepts of Competition.” Oxford Economic Papers, 47(1): 1-23. 